\title{
Kvalitetssikring eller forskning?
}

\author{
Etisk forhåndsvurdering og vitenskapelig metodikk er gjort til lovpålagte \\ krav for medisinske og helsefaglige forskningsprosjekter i helseforsk- \\ ningsloven. Hvor skal grensen trekkes mellom kvalitetssikring og medi- \\ sinsk og helsefaglig forskning? Og hvordan kan prinsippene i loven \\ anvendes med henblikk på doktorgradsarbeider?
}

I formålsbestemmelsen til helseforskningsloven fremgår det at hensikten med loven er å fremme god og etisk forsvarlig forskning (1). I kjernen av forsvarlighetskravet ligger en klar forutsetning om at all forskning som involverer mennesker, humant biologisk materiale og helseopplysning skal være basert på respekt for individets grunnleggende menneskerettigheter og menneskeverd. Samtidig skal loven gjennom et mest mulig enhetlig regelverk bidra til at ny kunnskap om helse og sykdom kommer befolkningen til gode. Tilsvarende betraktning kan også legges til grunn for en stor del av det kvalitetsforbedringsarbeidet som i dag utføres i helsetjenesten, der helseopplysninger og biologisk materiale fra enkeltpasienter benyttes i kvalitetsvurderingen av den helsetjeneste som ytes. Det er imidlertid slik at i motsetning til kvalitetssikringsprosjekter der det ikke oppstilles noen umiddelbare krav til etisk forhåndsvurdering og vitenskapelig metodikk, er dette blitt gjort til lovpålagte krav for medisinske og helsefaglige forskningsprosjekter i helseforskningsloven. Hvor skal så grensen trekkes mellom kvalitetssikring og medisinsk og helsefaglig forskning? Problemstillingen har både en normativ og materiell side ettersom det er virksomhetens reelle karakter som er avgjørende for hvilket regelsett som kommer til anvendelse, ikke nødvendigvis hva man velger å kalle virksomheten (2).

\section{Utfordrende grenseoppgang}

I praksis har grenseoppgangen kvalitetssikring og forskning vist seg å være utfordrende - om umulig i enkelte tilfeller - når myndighetsorgan, forskningsinstitusjonene og forskerne selv skal prøve å trekke et fornuftig skille mellom eksempelvis observasjonsstudier i kvalitetssikringsøyemed og epidemiologisk forskning. Selv om helseforskningsloven i §4 gir visse føringer, idet medisinsk og helsefaglig forskning defineres som «virksomhet som utføres med vitenskapelig metodikk for å skaffe til veie ny kunnskap om helse og sykdom», så er det fremdeles usikkert hva lovgiver har ment. Den nasjonale forskningskomité for medisin og helsefag (NEM) fremhevet da også $i$ et høringsinnspill at avgrensning mellom kvalitetssikring og forskning vil utgjør den største utfordring for de etiske komiteer i deres nye rolle og ansvar etter helseforskningsloven (3).

Grenseoppgangen mellom kvalitetssikring og forskning berører imidlertid ikke bare spørsmål om rettsanvendelse og lovligheten av et prosjekt. I tillegg kan det reises spørsmål om hva som kan og bør aksepteres som en del av et doktorgradsarbeid. Legger man til grunn at et doktorgradsarbeid skal vurderes i lys av anerkjente etiske normer for forskning, kan vi vanskelig se at et kvalitetssikringsprosjekt som involverer pasienter, deres biologiske materiale eller helseopplysninger kan aksepteres uten at prinsippene $\mathrm{i}$ helseforskningsloven legges til grunn, herunder krav om forhåndsgodkjenning av regional etisk komité (REK). Tilsvarende mener vi at de ulike samtykkebestemmelsene som gjøres gjeldende for henholdsvis kvalitets- og forskningsprosjekter, også kan være til hinder for å akseptere kvalitetssikring som del av et doktorgradsarbeid.

\section{Internasjonale retningslinjer}

Det er derfor behov for en mer vitenskapelig tilnærming til kvalitetsforbedring $i$ helsetjenesten generelt og klinisk virksomhet spesielt (4). Sentralt her står utviklingen av internasjonale retningslinjer for gjennomføring og publisering av kvalitetsforbedringsprosjekter, «SQUIRE guidelines» (5). Dette er retningslinjer som i det alt vesentlige sammenfaller med tilsvarende prinsipper lagt til grunn for epidemiologisk forskning (STROBE, og STREGA $(6,7)$ ), og som etter hva vi er kjent med, er akseptert som anerkjente vitenskapelige prinsipper både i relasjon til forskningsetikkloven og helseforskningsloven.

I 2008 ble det avlagt en doktorgrad ved universitetet i Bergen som er gjennomført i tråd med SQUIRE-kriteriene (8). At et kvalitetsforbedringsprosjekt som dette er akseptert og godkjent ut fra vitenskapelige kriterier som en doktorgrad, er i seg selv et viktig signal. SQUIRE-kriteriene gjør det lettere å planlegge større kvalitetsforbedringsprosjekter slik at de lar seg publisere i anerkjente fora. Men gjør gjennomføring i tråd med disse kriteriene det enklere å trekke grensen mellom kvalitetssikring og forskning?

De medisinske fakulteter bør i samarbeid med NEM/REK sørge for at kvalitetssikringsprosjekter som planlegges, gjennomføres og publiseres i tråd med SQUIREkriteriene gjennomgår en kritisk gransking $i$ henhold til kravet om «vitenskapelig metodikk». Dette må også gjelde for doktorgradsarbeider. Slik kan den usikkerheten som i dag eksisterer blant forskere og stipendiater vedrørende hva som kan aksepteres tatt med i et doktorgradsarbeid bli mindre.

\section{Peder Heyerdahl Utne}

peder.utne@fhi.no

Nasjonalt folkehelseinstitutt

Postboks 4404 Nydalen

0403 Oslo

Dag S. Thelle

Universitetet i Oslo

\section{Oppgitte interessekonflikter: Ingen}

\section{Litteratur}

1. Lov 2008-06-20 nr 44. Lov om medisinsk og helsefaglig forskning (helseforskningsloven). www.lovdata.no/all/hl-20080620-044.html [11.9.2009].

2. Simonsen S, Nylenna M. Helseforskningsrett Oslo: Gyldendal, 2005

3. Forskningsetiske komiteer, høringsuttalelse forslag til forskrift om organisering av medisinsk og helsefaglig forskning og forslag til endringer i registerforskriftene og forvaltningslovforskriften. ww.regjeringen.no/pages/2157677/Uttalelse forskningsetiske kommiteer.pdf (25.9.2009).

4. Holm HA. Fokus på kvalitetsforbedring, nå også i forskning. Tidsskr Nor Legeforen 2009; 129: 1236

5. SQUIRE Guidelines. www.squire-statement.org/ (25.9.2009).

6. von Elm E, Altman DG, Egger M et al. The Strengthening the Reporting of Observational Studies in Epidemiology (STROBE) statement: guidelines for reporting observational studies. PLoS Med 2007; 4 e296.

7. Little J, Higgins JP, loannidis JP et al. Strengthening the reporting of genetic association studies (STREGA): an extension of the STROBE statement. Eur J Epidemiol 2009; 24: 37-55.

8. von Plessen C. Kjemoterapi for pasienter med lungekreft. Doktorgrad. Bergen: Universitetet i Bergen, 2008. www.uib.no/info/dr_grad/2008/ VonPlessen_Christian.html (25.9.2009). 